\title{
ANALISIS KADAR PROTEIN DAN LEMAK PADA IKAN JULUNG-JULUNG ASAP (Hemiramphus far) ASAL KECAMATAN KAYOA MALUKU UTARA DENGAN METODE KJELDAHL DAN GRAVIMETRI
}

\author{
Mamat Pratama, Muzakkir Baits, Nurul Auliah A.R.Saman \\ Fakultas Farmasi Universitas Muslim Indonesia \\ Email : mamatpratamas.farm@gmail.com
}

\begin{abstract}
Content Analysis of Protein And Fats In fish smoked julung-julung (Hemiramphus far) Origin of North Maluku, Subdistrict Kayoa with Kjeldahl Method and Gravimetri Method. An investigation of analysis of protein and fat content in fish smoked julung-julung (Hemiramphus far) Origin Of North Maluku,District kayoa with kjeldahl method and gravimetri method. This study aimed to obtain scientific data about the content of protein and fat in fish smoked julung-julung (Hemiramphus far). This includes research on the protein nitrogen content of the test by Kjeldahl Method and analysis of fat content by using the method showed that the levels Gravimetri. The result showed that the samples of smoked fish fated to be unluckyfated to unlucky (Hemiramphus far) obtained A water content of $13,90 \%$, protein content of $71,03 \%$ and fat content $4,13 \%$ and in fish simple fated to be unlucky-fated to unlucky (Hemiramphus far) obtained B water content of $14,07 \%$, protein content of $71,67 \%$ and fat content $5,38 \%$.
\end{abstract}

Keywords : Smoked fish julung-julung, protein, fat, kjeldahl and gravimetri.

\section{PENDAHULUAN}

Pangan atau makanan yang di konsumsi pada dasarnya berfungsi sebagai sumber tenaga, memelihara atau mengganti jaringan sel tubuh yang rusak, mengatur metabolisme dan mengatur berbagai keseimbangan serta berperan dalam mekanisme pertahanan tubuh terhadap berbagai penyakit.

\section{Bahan pangan yang}

mengandung air, vitamin, mineral, kalori, protein, lemak dan karbohidrat banyak dijumpai pada buah, sayuran dan ikan. Sebagai elemen organik mineral merupakan salah satu zat yang diperlukan untuk metabolisme tubuh.Kekurangan zat gizi tersebut dalam tingkat ringan sekalipun dapat mengganggu kemampuan belajar, mengurangi produktivitas kerja bahkan dapat memperparah penyakit.(Winarno, 1992).

Protein merupakan komponen penting atau komponen utama.Dalam kehidupan, protein memegang peranan penting.Kita memperoleh protein dari hewan atau 
Analisis Kadar Protein Dan Lemak Pada Ikan Julung-Julung Asap (Hemiramphus far) Asal Kecamatan Kayoa Maluku Utara Dengan Metode Kjeldahl Dan Gravimetri

tumbuhan.Protein dari hewan ini salah satunya terdapat pada ikan yang digunakan sebagai pembentukan selsel tubuh. Fungsi protein adalah sebagai pembangun tubuh, pemberi tenaga dan juga sebagai pengatur kelangsungan proses di dalam tubuh (Poedjiadi, 1994).

Lemak adalah sekelompok ikatan organik yang terdiri atas unsurunsur Karbon $(\mathrm{C})$, Hidrogen $(\mathrm{H})$ dan Oksigen (O) yang mempunyai sifat dapat larut dalam zat-zat pelarut tertentu. Lemak sebagai sumber pembentuk jaringan lemak. Fungsi lemak adalah sebagai penghasil energi dan sebagai pembangun atau pembentuk susunan tubuh.

Ikan asap merupakan produk olahan hasil perikanan dengan bahan baku ikan yang mengalami perlakuan pengolahan dan pengasapan (SNI 2725.1, 2009). Menurut (Siswono, 2004) Kandungan gizi Ikan dapat menggantikan susu sebagai bahan pangan yang mempunyai nilai gizi tinggi dan kandungan mineral, lemak tak jenuh dan protein yang tersusun dalam asam amino esensial yang dibutuhkan untuk pertumbuhan tubuh dan kecerdasan manusia.

Salah satu ikan yang digunakan dalam penelitian ini adalah ikan julungjulung asap (Hemiramphus far) yang merupakan hasil pengolahan ikan dengan menggunakan sistem pengasapan yang memberikan rasa yang khas serta tekstur yang padat dan kering. Menurut (saanin, 1984) ikan julung-julung (Hemiramphus far) mengandung protein dan lemak.

Hal inilah yang mendasari perlunya dilakukan penelitian mengenai analisis kadar protein dan lemak pada ikan julung-julung asap (Hemiramphus far) dengan menggunakan metode Kjeldahl dan Gravimetri.

\section{METODE PENELITIAN}

\section{Alat dan Bahan}

Alat-alat yang diinginkan pada penelitian ini yaitu Blender, buret, botol semprot, cawan porselin, corong, eksikator, Erlenmeyer $100 \mathrm{ml}$ (pyrex), gegep besi, gelas ukur $100 \mathrm{ml}$ (pyrex), labu suling, labu ukur $100 \mathrm{ml}$, lemari asam, klem, pipit tetes, pipit volume 5 $\mathrm{ml}$ dan $10 \mathrm{ml}$, oven, rak tabung, seperangkat alat destilasi, seperangkat alat destruksi, statif, tabung destruksi, tabung reaksi (pyrex), timbangan analitik.

Bahan-bahan yang digunakan dalam peneltian ini yaitu Aquades, asam borat $3 \%$, asam sulfat $0,0171 \mathrm{~N}$, asam sulfat pekat, ikan julung-julung asap (Hemiramphus far), indikator brom kresol, Indikator metil merah, 
Analisis Kadar Protein Dan Lemak Pada Ikan Julung-Julung Asap (Hemiramphus far) Asal Kecamatan Kayoa Maluku Utara Dengan Metode Kjeldahl Dan Gravimetri

kertas label, kertas saring, kloroform, natrium hidroksida $40 \%$, penyumbat karet, kantong plastik dan campuran selenium.

\section{Prosedur Penelitian}

\section{Penentuan Kadar Air}

Prosedur penentuan kadar air dengan cara pemanasan (Sudarmadji, 2010) :

Terlebih dahulu cawan porselin dikeringkan selama 3-5 jam dalam oven pada suhu $100-105^{\circ} \mathrm{C}$, kemudian didinginkan dalam eksikator selama 15 menit dan ditimbang (a). Ditimbang 1 gr daging ikan julung-julung asap (b) dan dimasukkan ke dalam cawan porselin.Cawan porselin yang berisi sampel dimasukan ke dalam oven pada suhu $100-105^{\circ} \mathrm{C}$ dan dikeringkan selama 3-5 jam. Didinginkan cawan porselin yang berisi sampel dalam eksikator selama 15 menit, lalu ditimbang beratnya (selisih penimbangan tidak lebih dari $0,2 \mathrm{mg}$ ).

Dihitung kadar air:

$$
\begin{aligned}
\% \text { Kadar BK } & =\frac{c-a}{b} \times 100 \% \\
\% \text { Kadar air } & =100 \%-B K
\end{aligned}
$$

\section{Keterangan}

$$
\begin{aligned}
\mathrm{a}= & \text { Berat cawan kosong } \\
\mathrm{b}= & \text { Berat contoh } \\
\mathrm{C}= & \text { Berat cawan berisi sampel setelah } \\
& \text { dioven } \\
\mathrm{BK}= & \text { Berat kering }
\end{aligned}
$$

\section{Penentuan Kadar Protein}

Prosedur penentuan Nitrogen total dengan metode Kjeldahl (Sudarmadji, 2010) :

Ditimbang 1 gram daging ikan julung-julung asap (Hemiramphus far). Ditambahkan 2 gram campuran selenium dan $20 \mathrm{ml} \mathrm{H}_{2} \mathrm{SO}_{4}$ pekat kedalam labu kjeldahl. Didestruksi didalam lemari asam sampai larutan berubah warna menjadi jernih. Didinginkan hasil destruksi kemudian dimasukkan kedalam labu ukur $100 \mathrm{ml}$ dan diencerkan dengan aquades sampai batas tanda lalu dikocok. Dipipet larutan tersebut sebanyak $5 \mathrm{ml}$ dan dimasukkan kedalam labu suling kemudian ditambahkan dengan aquades $100 \mathrm{ml}$ mengunakan gelas ukur dan Ditambahkan $15 \mathrm{ml} \mathrm{NaOH}$ 40\% kemudian didestilasi. Disiapkan Erlenmeyer $100 \mathrm{ml}$ yang diberi indikator mix 3 tetes dan asam borat $2 \%$ guna untuk menampung hasil destilat.Dilakukan destilasi hingga diperoleh volume destilat sekitar 50 ml.Hasil destilasi kemudian dititrasi dengan asam sulfat $0,0171 \mathrm{~N}$ sampai larutan berubah dari hijau menjadi merah.Dihitung kadar protein: $\mathrm{V} \times \mathrm{N}$

$$
\% \text { Kadar Nt }=\frac{14 \times \mathrm{P}}{\text { Berat contoh }(\mathrm{mg})} \times 100 \%
$$

$\%$ Kadar protein $=\% \mathrm{~N} \times$ Faktor konversi 
Analisis Kadar Protein Dan Lemak Pada Ikan Julung-Julung Asap (Hemiramphus far) Asal Kecamatan Kayoa Maluku Utara Dengan Metode Kjeldahl Dan Gravimetri

\section{Keterangan}

$\mathrm{P}=$ Pengenceran

$\mathrm{V}=$ Volume asam sulfat

$\mathrm{N}=$ Normalitas larutan asam sulfat

$14=$ Berat ekivalen Nitrogen

$\mathrm{Fk}=6,25$ (Besarnya faktor perkalian $\mathrm{N}$ pada makanan)

\section{Penentuan Kadar Lemak}

Prosedur penentuan kadar lemak dengan metode gravimetri (Hasan, 2009) :

Ditimbang 1 gram daging ikan julung-julung asap (Hemiramphus far) (c gram). Dimasukkan sampel dalam tabung reaksi. Ditambahkan $10 \mathrm{ml}$ kloroform. Ditutup dengan penyumbat karet kemudian kocok dan biarkan bermalam. Disaring menggunakan kertas saring ke dalam tabung reaksi yang lain.Dipipet $5 \mathrm{ml}$ ke dalam cawan porselin yang telah diketahui beratnya (a gram). Dioven dengan suhu $100^{\circ} \mathrm{C}$ selama 3 jam atau biarkan bermalam. Dimasukkan kedalam eksikator \pm 30 menit. Ditimbang cawan porselin beserta lemak (b gram). Dihitung kadar lemak:

$\%$ Kadar Lemak $=\frac{P(b-a)}{C} \times 100 \%$

keterangan :

$\mathrm{P}=$ Pengenceran

$\mathrm{a}=$ Berat cawan kosong

$\mathrm{b}=$ Berat cawan berisi lemak setelah di oven

$\mathrm{c}=$ Berat contoh

\section{HASIL PENELITIAN}

Tabel 1. Hasil Analisis Kadar Air Ikan Julung-julung Asap (Hemiramphus far)

\begin{tabular}{ccc}
\hline No & Sampel & Kadar Air \\
\hline 1 & Ikan Julung-julung Asap (Hemiramphus far) A1 & $13,9 \%$ \\
2 & Ikan Julung-julung Asap (Hemiramphus far) A2 & $13,91 \%$ \\
3 & Ikan Julung-julung Asap (Hemiramphus far) B3 & $14,14 \%$ \\
4 & Ikan Julung-julung Asap (Hemiramphus far) B4 & $14 \%$ \\
\hline
\end{tabular}

Tabel 2. Hasil rata-rata Analisis Kadar Air Ikan Julung-julung Asap (Hemiramphus far)

\begin{tabular}{ccc}
\hline No & Sampel & Kadar Air \\
\hline 1 & Ikan Julung-julung Asap (Hemiramphus far) A & $13,90 \%$ \\
2 & Ikan Julung-julung Asap (Hemiramphus far) B & $14,07 \%$ \\
\hline
\end{tabular}

Tabel 3. Hasil Total Analisis Kadar Air Ikan Julung-julung Asap (Hemiramphus far)

\begin{tabular}{ccc}
\hline No & Sampel & Kadar Air \\
\hline 1 & Ikan Julung-julung Asap (Hemiramphus far) & $13,98 \%$ \\
\hline
\end{tabular}


Analisis Kadar Protein Dan Lemak Pada Ikan Julung-Julung Asap (Hemiramphus far) Asal Kecamatan Kayoa Maluku Utara Dengan Metode Kjeldahl Dan Gravimetri

Tabel 4. Hasil Analisis Kadar Protein dan Lemak Ikan Julung-julung Asap (Hemiramphus far)

\begin{tabular}{clcc}
\hline No & Sampel & $\begin{array}{c}\text { Kadar Nitrogen } \\
\text { Total }\end{array}$ & Kadar Lemak \\
\hline 1 & Ikan Julung-julung Asap (Hemiramphus far) A1 & $11,13 \%$ & $4,29 \%$ \\
2 & Ikan Julung-julung Asap (Hemiramphus far) A2 & $11,59 \%$ & $3,98 \%$ \\
3 & Ikan Julung-julung Asap (Hemiramphus far) B3 & $11,39 \%$ & $5,41 \%$ \\
4 & Ikan Julung-julung Asap (Hemiramphus far) B4 & $11,57 \%$ & $5,35 \%$ \\
\hline
\end{tabular}

Tabel 5. Hasil rata-rata Analisis Kadar Protein dan Lemak Ikan Julung-julung Asap (Hemiramphus far)

\begin{tabular}{cccc}
\hline No & Sampel & Kadar Protein & Kadar Lemak \\
\hline 1 & Ikan Julung-julung Asap (Hemiramphus far) A & $71,03 \%$ & $4,13 \%$ \\
2 & Ikan Julung-julung Asap (Hemiramphus far) B & $71,67 \%$ & $5,38 \%$ \\
\hline
\end{tabular}

Tabel 6. Hasil Total Analisis Kadar Protein dan Lemak Ikan Julung-julung Asap (Hemiramphus far)

\begin{tabular}{cccc}
\hline No & Sampel & Kadar Protein & Kadar Lemak \\
\hline 1 & Ikan Julung-julung Asap (Hemiramphus far) & $71,35 \%$ & $4,75 \%$ \\
\hline
\end{tabular}

\section{Keterangan :}

A $\quad=$ Sampel industri rumahan $A$

$\mathrm{B}=$ Sampel industri rumahan $\mathrm{B}$

\section{PEMBAHASAN}

Penelitian ini dilakukan dengan menganalisis kadar protein dan lemak pada sampel ikan julung-julung asap (Hemiramphus far) asal Kecamatan Kayoa Maluku Utara secara Kjeldahl dan Gravimetri. Penelitian ini menggunakan sampel ikan julungjulung asap (Hemiramphus far) karena sampel ini banyak dikonsumsi oleh masyarakat dalam kehidupan seharihari.

Protein merupakan komponen penting atau komponen utama. Dalam

kehidupan, protein memegang peranan penting yang berfungsi sebagai pembangun tubuh, pemberi tenaga dan juga sebagai pengatur kelangsungan proses di dalam tubuh.

Kebutuhan protein perorangan tergantung pada laju pertumbuhan dari berat badan.Orang dewasa memerlukan kira-kira 1 gram protein untuk setiap Kg/BB dan anak-anak 5-6 tahun dibutuhkan kira-kira 2 gram protein untuk tiap $\mathrm{Kg} / \mathrm{BB}$.

Selain protein, lemak juga memegang peranan penting dimana 
Analisis Kadar Protein Dan Lemak Pada Ikan Julung-Julung Asap (Hemiramphus far) Asal Kecamatan Kayoa Maluku Utara Dengan Metode Kjeldahl Dan Gravimetri

Lemak adalah sekelompok ikatan organik yang terdiri atas unsur-unsur Karbon $(\mathrm{C})$, Hidrogen $(\mathrm{H})$ dan Oksigen (O) yang mempunyai sifat dapat larut dalam zat-zat pelarut tertentu. Lemak sebagai sumber pembentuk jaringan lemak yang berfungsi sebagai penghasil energi dan sebagai pembangun atau pembentuk susunan tubuh.

Salah satu kebutuhan protein dan lemak yang cukup banyak adalah salah satunya terdapat pada ikan. Ikan yang digunakan dalam penelitian ini adalah ikan julung-julung asap (Hemiramphus far). Ikan julung-julung asap (Hemiramphus far) adalah ikan yang diawetkan oleh masyarakat dengan pengasapan menggunakan kayu bakau yang diasapi selama 3 hari 3 malam untuk mendapatkan rasa yang khas, tekstur daging yang padat dan kering sehingga ikan akan bertahan lama pada saat dikonsumsi.

Tujuan dari pengasapan yaitu lebih tahan lama, meningkatkan citra rasa dan warna luar terutama pada daging. Penelitian ini didasarkan pada dua penentuan yaitu penentuan kadar protein dengan metode kjedahl dan penentuan kadar lemak dengan metode gravimetri.

Penentuan kadar protein dengan cara kjedahl dibagi menjadi 3 tahap yaitu tahap destruksi, destilasi dan titrasi. Pada tahap destruksi sampel ikan julung-julung asap (Hemiramphus far) dipanaskan dengan asam sulfat pekat sehingga terjadi proses destruksi, dimana nitrogennya akan berubah menjadi amonium sulfat $\left.\left(\mathrm{NH}_{4}\right)_{2} \mathrm{SO}_{4}\right)$. Untuk mempercepat proses destruksi ditambahkan campuran selenium sebagai katalisator. Campuran selenium dapat mempercepat proses oksidasi karena zat tersebut dapat menaikkan titik didih. Proses destruksi selesai apabila larutan menjadi jernih. Pada tahap destilasi amonium sulfat dipecah menjadi amonia $\left(\mathrm{NH}_{3}\right)$ dengan penambahan natrium hidroksida $(\mathrm{NaOH})$.Amonia $\quad\left(\mathrm{NH}_{3}\right) \quad$ yang dibebaskan selanjutnya ditangkap oleh asam borat yang telah berisi indikator campuran metil merah dan brom kresol dalam wadah penampung dalam jumlah yang berlebih.Kemudian dititrasi dengan menggunakan asam sulfat yang bertujuan untuk mengukur asam yang bereaksi dengan amonia $\left(\mathrm{NH}_{3}\right)$. Titik akhir titrasi ditandai dengan perubahan larutan dari hijau menjadi merah.

Protein merupakan hasil kali dari jumlah nitrogen dalam sampel dengan faktor 6,25 , dimana faktor 6,25 berasal dari kadar nitrogen rata-rata di 
Analisis Kadar Protein Dan Lemak Pada Ikan Julung-Julung Asap (Hemiramphus far) Asal Kecamatan Kayoa Maluku Utara Dengan Metode Kjeldahl Dan Gravimetri

dalam protein adalah 16\%, maka protein yang terkandung di dalam sampel (gram) nitrogen adalah 6,25 $\mathrm{x}$ sampel (gram). Dimana 6,25 adalah faktor konversi nitrogen menjadi protein. Berdasarkan hasil penelitian, diperoleh kadar protein total pada ikan julung-julung asap (Hemiramphus far) adalah $71,35 \%$.

Penentuan kadar lemak yang terkandung pada ikan julung-julung asap (Hemiramphus far) didasarkan pada prinsip pengujian metode ekstraksi yang bertujuan untuk menarik komponen-komponen yang terkandung di dalam sampel ikan julung-julung asap (Hemiramphus far) dengan menggunakan pelarut kloroform dimana kloroform digunakan karena lemak merupakan senyawa non polar sehingga untuk melarutkan lemak digunakan juga pelarut non polar. Selanjutnya, untuk mendapatkan lemaknya maka pelarut kloroform diuapkan dengan cara diovenkan. Analisis perhitungan kadar lemak menggunakan metode gravimetri berdasarkan perbandingan berat lemak kasar dengan berat sampel awal. Berdasarkan hasil penelitian, diperoleh kadar lemak total pada ikan julung-julung asap (Hemiramphus far) adalah $4,75 \%$. Dari penelitian yang dilakukan didapatkan kadar protein sebesar $71,35 \%$ dimana kadar protein ikan julung-julung asap (Hemiramphus far) lebih menurun dibandingkan dengan kadar ikan julung-julung (Hemiramphus far) yang masih segar sebesar 79,98\%. Begitupun dengan kadar lemak ikan julung-julung asap (Hemiramphus far) yang didapatkan sebesar $4,75 \%$ lebih meningkat dibandingkan dengan dengan kadar ikan julung-julung (Hemiramphus far) yang masih segar sebesar $1,45 \%$ dan kadar air ikan ulung-julung asap (Hemiramphus far) yang didapatkan sebesar 13,98\% lebih menurun dibandingkan dengan kadar air ikan ulung-julung asap (Hemiramphus far) yang masih segar sebesar $18,02 \%$.

Dari hasil penelitian didapatkan bahwa ada perbedaan dari kedua sampel dimana sampel ikan julungjulung asap (Hemiramphus far) A dari desa buli diperoleh kadar air sebesar $13,90 \%$, kadar protein sebesar $71,03 \%$ dan kadar lemak sebesar $4,13 \%$ sedangkan pada sampel ikan julungjulung asap (Hemiramphus far) B dari desa ligua diperoleh kadar air sebesar $14,07 \%$, kadar protein sebesar $71,57 \%$ dan kadar lemak sebesar 5,38\%. Dari data yang diperoleh dapat disimpulkan bahwa perbedaan nilai yang didapatkan disebabkan oleh faktor pengasapan dari kedua ikan tersebut 
Analisis Kadar Protein Dan Lemak Pada Ikan Julung-Julung Asap (Hemiramphus far) Asal Kecamatan Kayoa Maluku Utara Dengan Metode Kjeldahl Dan Gravimetri

diakibatkan dari tinggina suhu

Gadjamada

University

pengasapan atau bahan pembakaran yang digunakan terlalu banyak.

\section{KESIMPULAN}

Berdasarkan hasil analisis kadar protein dan lemak pada ikan julung-julung asap (Hemiramphus far) dapat disimpulkan bahwa sampel ikan julung-julung asap (Hemiramphus far) A diperoleh kadar air sebesar 13,90\%, kadar protein sebesar 71,03\% dan kadar lemak sebesar $4,13 \%$ dan pada sampel ikan julung-julung asap (Hemiramphus far) B diperoleh kadar air sebesar 14,07\%, kadar protein sebesar $71,67 \%$ dan kadar lemak sebesar $5,38 \%$.

\section{DAFTAR PUSTAKA}

Anjasari, Bonita. 2010. Pangan Hewani Fisiologi Pasca Mortem dan Teknologi. Penerbit Graha Ilmu. Bandung.

Apriyantono. 1989. Analisa Pangan Debdikbud, Dikrektorat Jendral Pendidikan Tinggi Pusat antar Universitas Pangan dan Gizi, IPB. Jakarta.

Bassett, J. et al. 1994. Vogel Kimia Analisis Kuantitatif Organik. Penerbit Buku Kedokteran EGC. Jakarta.

Buckle, K.A, dkk. 1987. Ilmu Pangan, Diterjemahkan Oleh Hari Purnomo Adiona. Penerbit Universitas Indonesia. Jakarta.

Gaman, P.M., dan Sherrington, K.B. 1994. Ilmu Pangan Edisi Kedua.

Press.Yogyakarta.

Hasan.2009. Penentuan Kadar Lemak dengan Alat Sederhana. Universitas Hasanudin. Makassar.

Kartasapoetra, Drs.G. 2006.IImu Gizi Korelasi Gizi, Kesehatan dan Produktivias Kerja. Penerbit Rineka Cipta. Jakarta.

Khopkar.S.M. 1999.Konsep Dasar Kimia Analitik. Penerbit Universitas Indonesia.UI-Press. Jakarta.

Masuda, Hajime. 1993. Sea Fishes Of The Word. Published by YAMAKEI. Japan.

Muchtadi, T.R. $1992 . \quad$ IImu Pengetahuan Bahan Pangan. Petunjuk Laboratrium. Pusat Antar Universitas Pangan dan Gizi.Institut Pertanian Bogor. Bogor.

Moeljanto. R. 1992. Pengasapan dan Fermentasi Ikan. Penebar Swadaya. Jakarta.

Poedjiadi, A. 1994.Dasar-dasar Biokimia. Penerbit Universitas Indoensia UI-Press. Jakarta.

Rivai, Harrizul. $1995 . \quad$ Asas Pemeriksaan Kimia. Penerbit Universitas Indonesia, UI-Press. Jakarta.

Saanin, H. 1984. Taksonomi dan Kunci Identifikasi Ikan jilid 1 dan 2. Penerbit Bina Cipta. Bogor.

Saman, R.M, Serhington, K.B. 1994.llmu Pangan. Pengantar Ilmu Pangan dan Mikrobiologi. Penerbit UGM. Yogyakarta. 
Analisis Kadar Protein Dan Lemak Pada Ikan Julung-Julung Asap (Hemiramphus far) Asal Kecamatan Kayoa Maluku Utara Dengan Metode Kjeldahl Dan Gravimetri

Sediaoetomo, A.C. 2002.IImu Gizi Untuk Mahasiswa dan Profesi Jilid I, Cetakan Keempat. Penerbit Dian Rakyat. Jakarta.

Siswono.2004. Bahan Pangan dan Ikan. Penerbit Asdi Mahasatya. Jakarta.

Sudarmadji, S. 1984. Analisis Bahan Makanan dan Pertanian. Penerbit Liberty. Yogyakarta.

Sudarmadji, S. 2010. Prosedur Analisa Untuk Bahan Makanan dan Pertanian. Penerbit Liberty. Yogyakarta.

Suhardjo. 1999. Prinsip-prinsip IImu Gizi. Penerbit Kanisius. Yogyakarta.
Standar Nasional Indonesia.2009. Cara Uji Makanan dan MinumanBagian 1 Spesifikasi. SNI 2725.1:2009.

Toha, Abdul Hamid. A. Biokimia Metabolisme Biomolekul. 2001. Penerbit Alfabeta. Manokowari.

Winarno, F. G. 2002. Pangan, Gizi, Teknologi dan Konsumen. Gramedia. Jakarta.

Winarno, F.G. 1992. Kimia Pangan dan Gizi. Penerbit PT. Gramedia Pustaka Utama. Jakarta.

Wirahadikusumah, Muhammad. 1997. Biokimia Protein, Enzim dan Asam Nukleat. Penerbit ITB. Bandung. 